\title{
The human corpus luteum: which cells have progesterone receptors?
}

\author{
Jacqueline A Maybin and W Colin Duncan \\ Obstetrics and Gynaecology, Department of Reproductive and Developmental Sciences, University of Edinburgh, \\ Royal Infirmary of Edinburgh - Little France, 49 Little France Crescent, Old Dalkeith Road, Edinburgh EH16 4SB, \\ UK
}

Correspondence should be addressed to W C Duncan; Email: W.C.Duncan@ed.ac.uk

\begin{abstract}
Studies comparing the regressing corpus luteum with the rescued corpus luteum have demonstrated that human chorionic gonadotrophin (hCG) has effects on cell types that do not express hCG receptors. As progesterone synthesis is hCG dependent and the corpus luteum has been shown to express genomic progesterone receptors, progesterone is a candidate molecule for these paracrine effects. This study aimed to define the cellular localisation of progesterone receptors in the human corpus luteum using dual-staining immunohistochemistry for genomic progesterone receptors and specific cellular markers. Wellcharacterised corpora lutea $(n=12)$ from different stages of the luteal phase were studied. The same distribution was

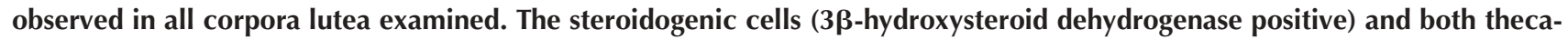
lutein (17 $\alpha$-hydroxylase positive) and granulosa-lutein (aromatase positive) express progesterone receptors, as do stromal fibroblasts (vimentin positive, fibroblast antigen positive). Vascular endothelial cells (CD31 positive), pericytes ( $\alpha$-smooth muscle actin positive), macrophages (CD68 positive) and fibroblasts within the central clot do not express nuclear progesterone receptors. Progesterone is a candidate messenger molecule for the effects of hCG on the matrix metalloproteinase-producing stromal fibroblasts. Some of the effects of hCG on steroidogenic cells may be mediated by progesterone, but its effects on blood vessels and macrophages require alternate paracrine signalling mechanisms. In addition, there appears to be at least two fibroblast populations in the corpus luteum.

Reproduction (2004) 128 423-431
\end{abstract}

\section{Introduction}

In a non-conception cycle, the human corpus luteum undergoes luteolysis with a loss of functional and structural integrity. The molecular events involved in luteolysis and how they are prevented by exposure to human chorionic gonadotrophin (hCG) remain unclear. We have developed a system to collect and study carefully dated human corpora lutea from throughout the luteal phase. In addition, we have been able to study luteal rescue by treating women with exogenous hCG to mimic the hormonal changes of early pregnancy prior to collection of the corpus luteum (Duncan 2000). This has allowed us to study the late luteal corpus luteum in the presence and absence of hCG.

These studies have revealed that the influx of macrophages into the corpus luteum in the late luteal phase is not seen in the presence of hCG (Duncan et al. 1998a). They have also demonstrated that matrix metalloproteinase (MMPs), notably MMP-2, increase in the late luteal phase and that this increase is not seen in the presence of
hCG (Duncan et al. 1998b). In addition, mRNA in situ hybridisation identified the main cellular source of MMP-2 in the corpus luteum to be stromal fibroblasts (Duncan et al. 1998b). A further study showed an increase in endothelial cell proliferation, and endothelial cell and pericyte area in the rescued corpus luteum of simulated early pregnancy (Wulff et al. 2001a). It was clear that hCG had marked effects on the corpus luteum during luteal rescue.

hCG causes its effects by binding to, and activating, the luteinising hormone $(\mathrm{LH})$ receptor, a seven transmembrane-domain G protein-coupled glycoprotein receptor. The LH/hCG receptor is localised to the steroidogenic cells of the corpus luteum (Nishimori et al. 1995, Duncan et al. 1996a). However, it was also clear that neither macrophages, the stromal fibroblasts that are the main source of MMP-2 expression, nor blood vessels express $\mathrm{LH} / \mathrm{hCG}$ receptors that are detectable by mRNA in situ hybridisation (Duncan et al. 1996a, 1998a,b). These receptors are present on the steroidogenic cells of the corpus luteum. This led us to hypothesise that macrophage 
influx and MMP-2 expression are influenced by steroidogenic cell products (Duncan 2000).

One strategy to identify putative paracrine molecules is to investigate factors synthesised in steroidogenic cells that have receptors on other cell types in the corpus luteum. It has been known for some years now that the corpus luteum of a variety of species including humans express genomic progesterone receptors (Hild-Petito et al. 1988, Suzuki et al. 1994). The possible paracrine effects of progesterone in the corpus luteum are still not clear however (Rothchild 1996, Vega \& Devoto 1997, Stouffer 2003). As progesterone is hCG dependent, increases during luteal rescue and falls in the late luteal phase, it is an excellent candidate molecule for some of the effects of hCG during luteal rescue (Duncan 2000). This study aimed to identify the cell types capable of responding to progesterone in the corpus luteum by co-localising nuclear genomic progesterone receptors with specific cellular markers using dual-staining immunohistochemistry.

\section{Materials and Methods}

\section{Source of reagents}

All reagents were obtained from Sigma Chemical (Poole, Dorset, UK) unless otherwise stated. The mouse monoclonal antibody to human progesterone receptor, recognising both $\mathrm{A}$ and $\mathrm{B}$ forms, was obtained from Novocastra Laboratories Ltd (Newcastle, Tyne \& Wear, UK). The polyclonal rabbit antibody to human $17 \alpha$-hydroxylase was kindly provided by Professor M R Waterman (Vanderbilt University, Nashville, TN, USA). The polyclonal rabbit antibody to human placental type I $3 \beta$-hydroxysteroid dehydrogenase (3 $\beta$-HSD) was supplied by Professor V Luu-The (CHUL Research Centre, Quebec, Canada). The mouse monoclonal antibody to aromatase was provided by Professor E Simpson (PHIMR, Clayton, Victoria, Australia). The mouse monoclonal antibodies to CD68, CD31, vimentin and $\alpha$-smooth muscle actin ( $\alpha$-SMA) were all obtained from Dako Ltd (Ely, Cambs, UK). The mouse monoclonal antibody to human fibroblast antigen was obtained from Oncogene Research (Boston, MA, USA). Secondary antibodies and the detection systems were either obtained from Vector Laboratories Ltd (Southgate, Peterborough, Cambs, UK) or from Dako Ltd.

\section{Collection of tissue}

Human corpora lutea were collected at the time of surgery from women undergoing hysterectomy for benign conditions $(n=12)$. All women had regular cycles and had not received any form of hormonal treatment in the 3 months prior to taking part in the study. Prior to surgery the women collected a daily early morning urine sample and the corpora lutea were dated on the basis of the urinary LH surge as described previously (Duncan et al. 1996a, Duncan 2000). In this study, five corpora lutea were classified as early luteal $(\mathrm{LH}+1$ to $\mathrm{LH}+5)$, four as mid-luteal $(\mathrm{LH}+6$ to $\mathrm{LH}+10)$ and three as late luteal $(\mathrm{LH}+11$ to $\mathrm{LH}+14)$. In all cases an endometrial biopsy corroborated our urinary-based tissue-dating system. The collection of human corpora lutea, after informed consent, was approved by the reproductive medicine subcommittee of the Lothian research ethics committee.

\section{Immunohistochemistry}

Tissues were fixed in $4 \%$ paraformaldehyde for $24 \mathrm{~h}$ and embedded in paraffin wax for subsequent immunohistochemical examination. Sections $(5 \mu \mathrm{m})$ were cut onto poly-L-lysine-coated slides, dewaxed and rehydrated into distilled water. Antigen retrieval was used as described in Table 1 . When proteolytic digestion was required, sections were incubated for $30 \mathrm{~min}$ at $37^{\circ} \mathrm{C}$ in $0.1 \%$ trypsin with $0.1 \%$ calcium chloride buffered with $0.25 \mathrm{M}$ Tris- $\mathrm{HCl}$. When microwave retrieval was required, slides were placed in a $0.01 \mathrm{M}$ sodium citrate buffer, pH6, microwaved at $450 \mathrm{~W}$ for two rounds of $5 \mathrm{~min}$ and left to stand for $20 \mathrm{~min}$.

If peroxidase detection systems were used endogenous peroxidase was blocked in a $1 \%$ solution of $30 \%$ hydrogen peroxide. Tissues were permeabilised with $0.1 \%$ Triton in phosphate-buffered saline and incubated for $1 \mathrm{~h}$ with normal serum block of the same species in which the secondary antibody was raised (Table 1). The primary antibody was applied at the working concentration (Table 1) diluted in blocking serum or buffer and incubated for $18 \mathrm{~h}$ at $4{ }^{\circ} \mathrm{C}$. The primary antibody was replaced with nonspecific $\lg \mathrm{G}$ at the same concentration where possible or omitted altogether in the negative controls. After washing, the slides were incubated with the secondary antibody for $30 \mathrm{~min}$ at room temperature (Table 1).

For peroxidase detection systems, $A B C$ linked to HRP was added for $1 \mathrm{~h}$ and antibody binding was visualised using $\mathrm{DAB}$ to give a brown colour or DAB with nickel to give a black end product. In some cases, haematoxylin counterstaining was used to aid visualisation of the section. For the AP detection system, ABC-AP was added for $1 \mathrm{~h}$ and antibody binding was visualised with NBT to give a blue colour. When the APAAP detection method was used the non-biotinylated secondary was added for $30 \mathrm{~min}$ followed by the tertiary APAAP complex for a further $30 \mathrm{~min}$. NBT was used to colour regions of antibody binding blue.

Dual staining immunohistochemistry involved detecting the anti-progesterone receptor antibody first followed by detection of the secondary antibody. Antigen retrieval was used only for the first primary antibody and the protocol adapted accordingly depending on which antibodies were being studied (Table 1 ). The slides were dehydrated and mounted with pertex mounting medium before analysis. The optimal conditions for each antibody and antibody combination were detected in many trial runs. All sections were studied by two independent observers by high 


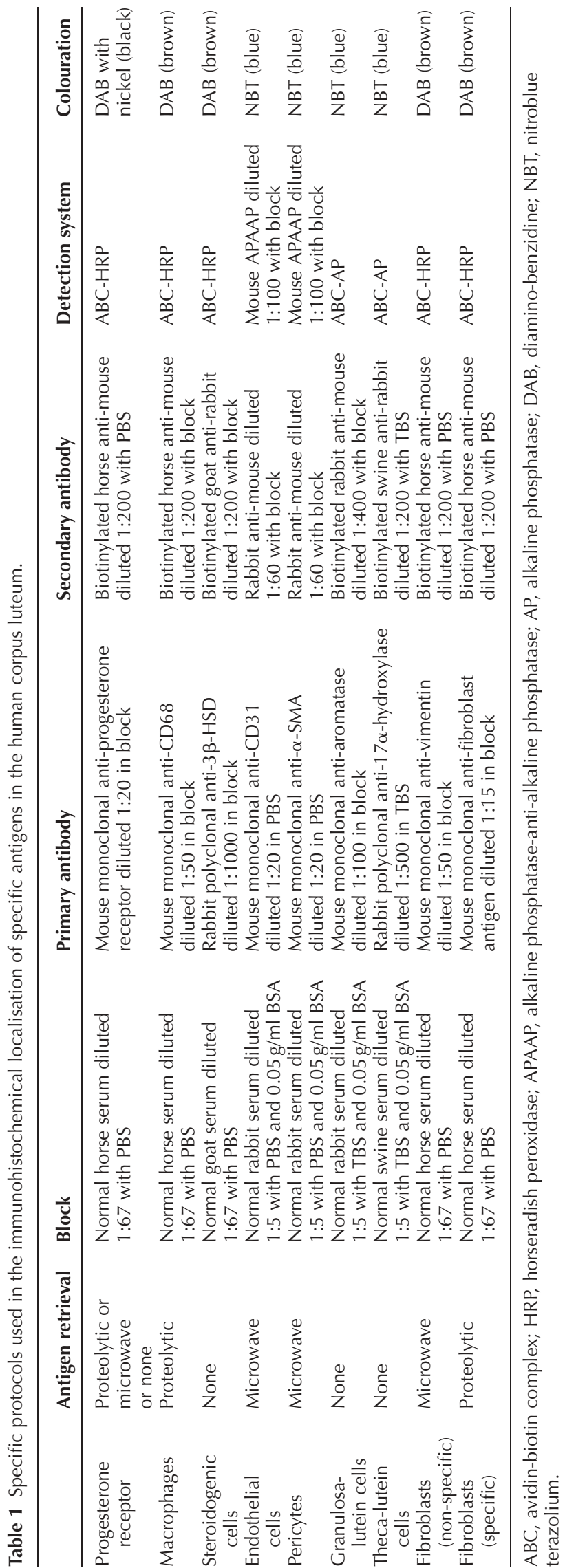

power microscopy. The presence of nuclear progesterone receptor staining in the same cells as the second primary antibody to various cytoplasmic components was carefully noted.

\section{Results}

\section{Progesterone receptor in the human corpus luteum}

Specific nuclear staining for the genomic progesterone receptors was detected in the human endometrial tissues used as positive controls (Fig. 1a). As described in several other studies, the human corpus luteum expresses nuclear receptors to the progesterone it produces (Fig. 1b). However, the corpus luteum has several different cellular compartments and major cell types. It was clear that more than one cell type expressed these progesterone receptors (Fig. 1b). No staining could be detected in negative control serial sections.

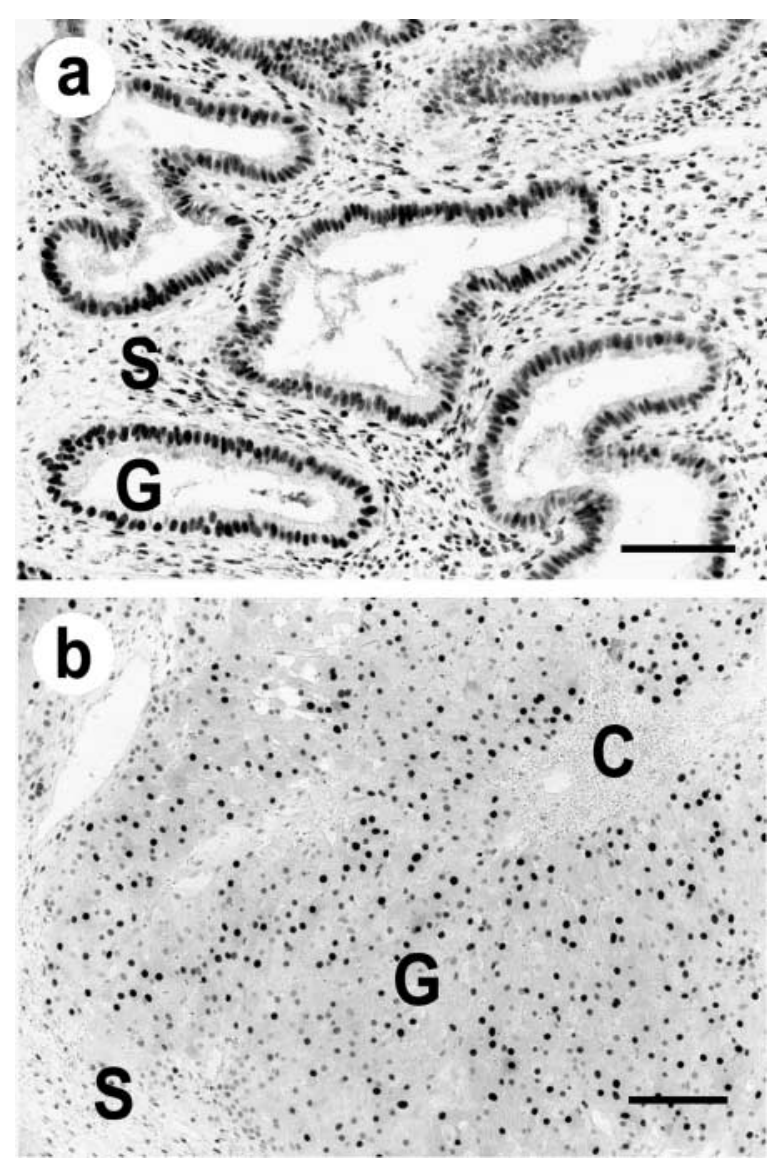

Figure 1 (a) A sample of early luteal phase endometrium immunostained for genomic progesterone receptors (black). Specific nuclear staining can be detected in both the stromal cells (S) and the glandular cells (G). (b) Section of a mid-luteal corpus luteum demonstrating specific immunostaininng for nuclear progesterone receptors. The stromal (S) cells, granulosa-luteal cells (G) and central clot (C) are clearly visible at this magnification. The sections are not counterstained and the scale bar $=50 \mu \mathrm{m}$. 


\section{Steroidogenic cells in the corpus luteum}

The human corpus luteum contains two distinct populations of steroidogenic cells. The granulosa-lutein cells are derived from the follicular granulosa cells and can be specifically localised by immunostaining for P450-aromatase (Fig. 2a). The theca-lutein cells are found in discrete areas around the periphery of the granulosa-lutein cells. They can be specifically identified by immunostaining for $17 \alpha$-hydroxylase (Fig. 2b). Immunostaining for $3 \beta$-HSD will detect steroidogenic cells in the corpus luteum including both granulosa-lutein and theca-lutein cells.

The steroidogenic cells of the corpus luteum expressed nuclear progesterone receptors (Fig. 2c). Some steroidogenic cells had intense immunostaining and other cells had little immunostaining. This variation in staining intensity was present in all sections at all stages of the luteal phase. The intensity of progesterone receptor immunostaining for each individual cell did not appear to reflect the staining intensity for $3 \beta-\mathrm{HSD}$ of that cell (Fig. 2c). Both granulosa-lutein cells and theca-lutein cells exp ressed immunostaining for nuclear progesterone receptor at all stages of the luteal phase and in all sections examined (Fig. 2d) (Table 2).

\section{Vascular cells in the corpus luteum}

Mature blood vessels consist of endothelial cells surrounded by pericytes. We identified pericytes by immunostaining for $\alpha$-SMA. Dual-staining immunohistochemistry revealed that pericytes did not express genomic progesterone receptors (Fig. 3a). This was seen in all areas of each section at all stages of the luteal phase (Table 2). Endothelial cells were identified by immunostaining for CD31. Careful analysis of each section did not reveal any dual staining for CD31 and progesterone receptors in all tissue sections studied (Fig. 3b). However, there were stromal
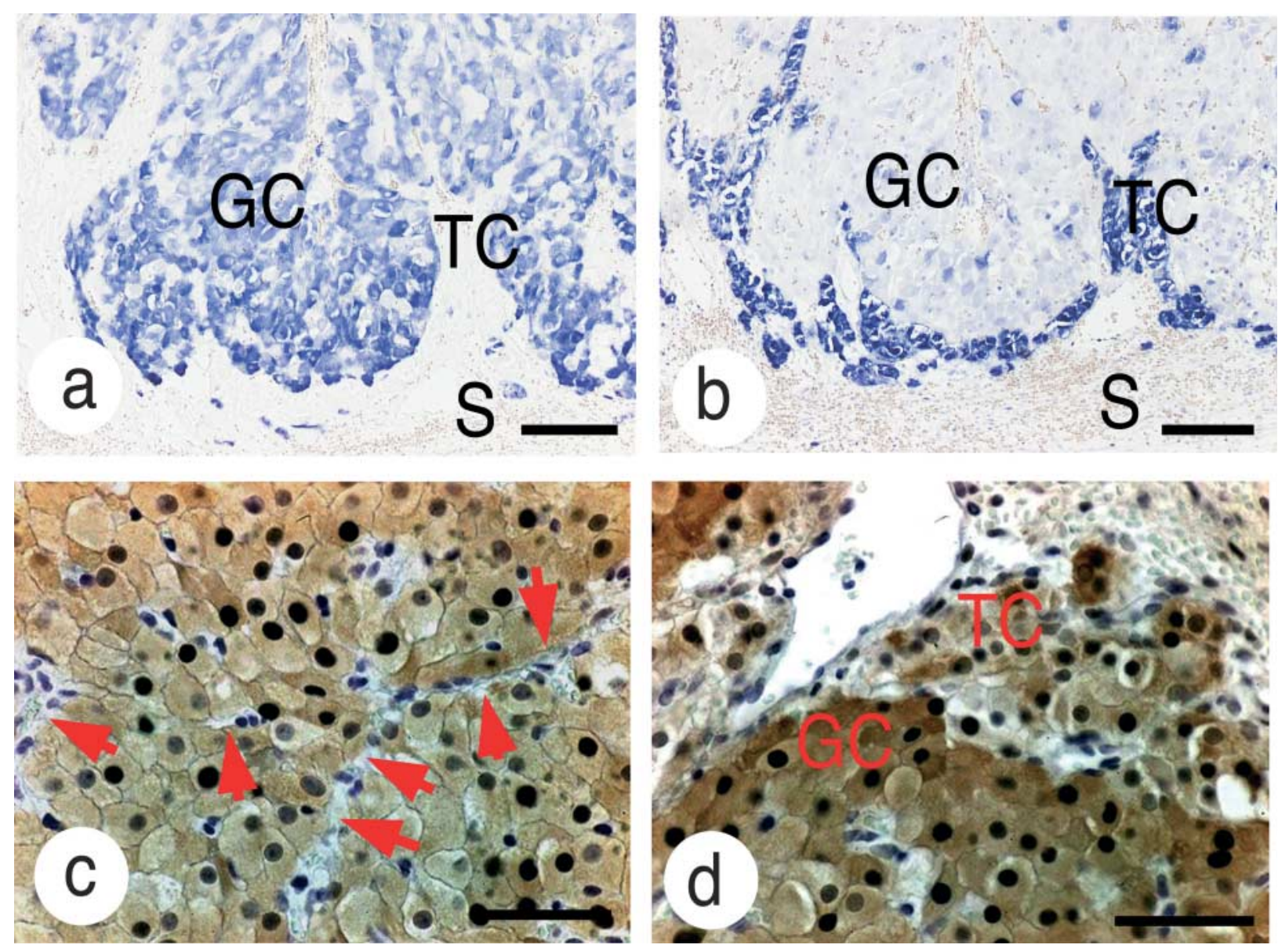

Figure 2 (a) Section of another mid-luteal human corpus luteum immunostained for aromatase (blue). The granulosa-lutein (GC) cells are stained while the theca-lutein (TC) cells are not immunostained. (b) Serial section immunostained for $17 \alpha$-hydroxylase (blue). The theca-lutein cells (TC) are clearly visible around the periphery of, and separate from, the granulosa lutein (GC) cells. The stroma(s) can be identified in each section although they have not been counterstained. (c) Section of a mid-luteal corpus luteum immunostained for $3 \beta$-HSD (brown) and genomic progesterone receptors (black). Although there is variation of staining intensity for progesterone receptors, the steroidogenic cells (brown) do express genomic receptors to the progesterone they produce. The specificity of staining is clear as blood vessels (arrows) are not immunostained. (d) An early luteal corpus luteum showing both the theca-lutein (TC) and granulosa-lutein (GC; brown) cells to express progesterone receptors (black). These sections are counterstained with haematoxylin for clarity. In all cases the scale bars represent $50 \mu \mathrm{m}$. 
Table 2 The presence and intensity of immunostaining for progesterone in the cell populations highlighted by dual staining immunohistochemistry.

\begin{tabular}{lccc}
\hline & \multicolumn{3}{c}{ Dual stain with nuclear progesterone } \\
receptors
\end{tabular}

$\mathrm{CL}$, corpus luteum.

cells around blood vessels, outside the pericyte layer, that did not immunostain for $3 \beta-\mathrm{HSD}$ but expressed genomic progesterone receptors (Fig. 3a).

\section{Fibroblasts in the corpus luteum}

We used vimentin as a marker of fibroblasts. However, this is a non-specific marker and, because of its origin, it immunostains steroidogenic cells as well (Fig. 3c). However, a specific fibroblast antibody was able to clearly delineate the fibroblasts in the corpus luteum (Fig. 3d). This showed fibroblasts in the outer stroma, scattered in the central clot but also in a perivascular distribution outside the pericytes around blood vessels as suggested above. Unfortunately, because of technical difficulties with this antibody when used for dual staining, we had to use vimentin as a fibroblast marker for dual-staining immunohistochemistry. We were able to compare it with serial sections stained with the fibroblast antibody and $3 \beta-H S D$ to be sure that fibroblasts were clearly identified. This showed that stromal and perivascular fibroblasts expressed genomic progesterone receptors but that the fibroblasts present within the central clot did not express progesterone receptors (Fig. $3 \mathrm{e}, \mathrm{f}$ and $\mathrm{g}$ ). This pattern was consistent and seen in all corpora lutea from all stages of the luteal phase (Table 2).

\section{Macrophages in the corpus luteum}

Macrophages were identified by immunostaining for CD68 (Fig. 3h). Macrophages were clearly visible in the stroma and within the steroidogenic cell layers. It was clear on dual staining of the macrophages with progesterone receptors that macrophages did not express immunodetectable genomic progesterone receptors (Fig. 3i). This was true in all areas of each section at all stages of the luteal phase (Table 2).

\section{Discussion}

Primate corpora lutea express genomic receptors to the progesterone they produce. This has been previously documented using immunohistochemistry (Hild-Petito et al.
1988), radioligand binding assays (Slayden et al. 1994), Western blotting (Duffy et al. 1997) and Northern blotting (Hild-Petito \& Fazleabas 1997). We have confirmed that the human corpus luteum expresses genomic progesterone receptors which can be detected by immunohistochemistry (Horie et al. 1992, Suzuki et al. 1994), and have expanded on previous studies by investigating which cell types in the corpus luteum clearly express these progesterone receptors. This is important, as steroidogenic cells have a major role in the control of luteal development and regression. In early pregnancy, hCG maintains steroidogenic cell progesterone synthesis and rescues the corpus luteum from luteolysis (Stouffer et al. 1987, Duncan et al. 1999). We have shown that hCG has major effects on luteal fibroblasts, macrophages and blood vessels (Duncan 2000) which do not express $\mathrm{LH}$ receptors. The paracrine molecules involved in these effects remain unclear. There is no doubt, however, that progesterone is an attractive candidate molecule for some of these paracrine interactions (Duncan 2000, Stouffer 2003). We have described the cell types capable of responding to progesterone through genomic progesterone receptors.

We have found that some luteal fibroblasts express progesterone receptors. As the staining intensity appeared to be consistent throughout, these fibroblasts are able to respond to progesterone at all stages of the luteal phase. Fibroblasts have roles during luteolysis and luteal rescue. The expression of MMPs, notably MMP-2, is increased during luteolysis and inhibited by hCG during luteal rescue (Duncan et al. 1998b). Although several cell types may express MMPs, it is clear that the major source of both MMP-2 and MMP-1 in the human corpus luteum is fibroblasts (Duncan et al. 1998b). It is now clear that both stromal and perivascular fibroblasts express progesterone receptors. Progesterone has a regulatory role in the expression of MMPs in the endometrium (Salamonsen et al. 1997, Curry \& Osteen 2003) and progesterone withdrawal up-regulates MMP-1 in the corpus luteum (Stouffer 2003). Studies on the effect of progesterone on ovarian fibroblast gene expression in vitro will help determine whether progesterone is involved in the local control of fibroblast function in the corpus luteum.

We have also found that steroidogenic cells, both theca-lutein and granulosa-lutein cells, express progesterone receptors. In our study, immunostaining was detected in steroidogenic cells at all stages of the luteal phase. However, of all the cell types examined, immunostaining of the steroidogenic cells was the most variable across the luteal phase. These dual-staining studies were designed to investigate localisation rather than variation in progesterone receptor immunostaining. However, previous reports have suggested a reduction in progesterone receptor immunostaining in the late luteal phase (Suzuki et al. 1994, Hild-Petito \& Fazleabas 1997). As steroidogenic cell immunostaining was most variable, it is likely that these reports reflect changes in the immunostaining of the steroidogenic cell compartment. Our detection of 


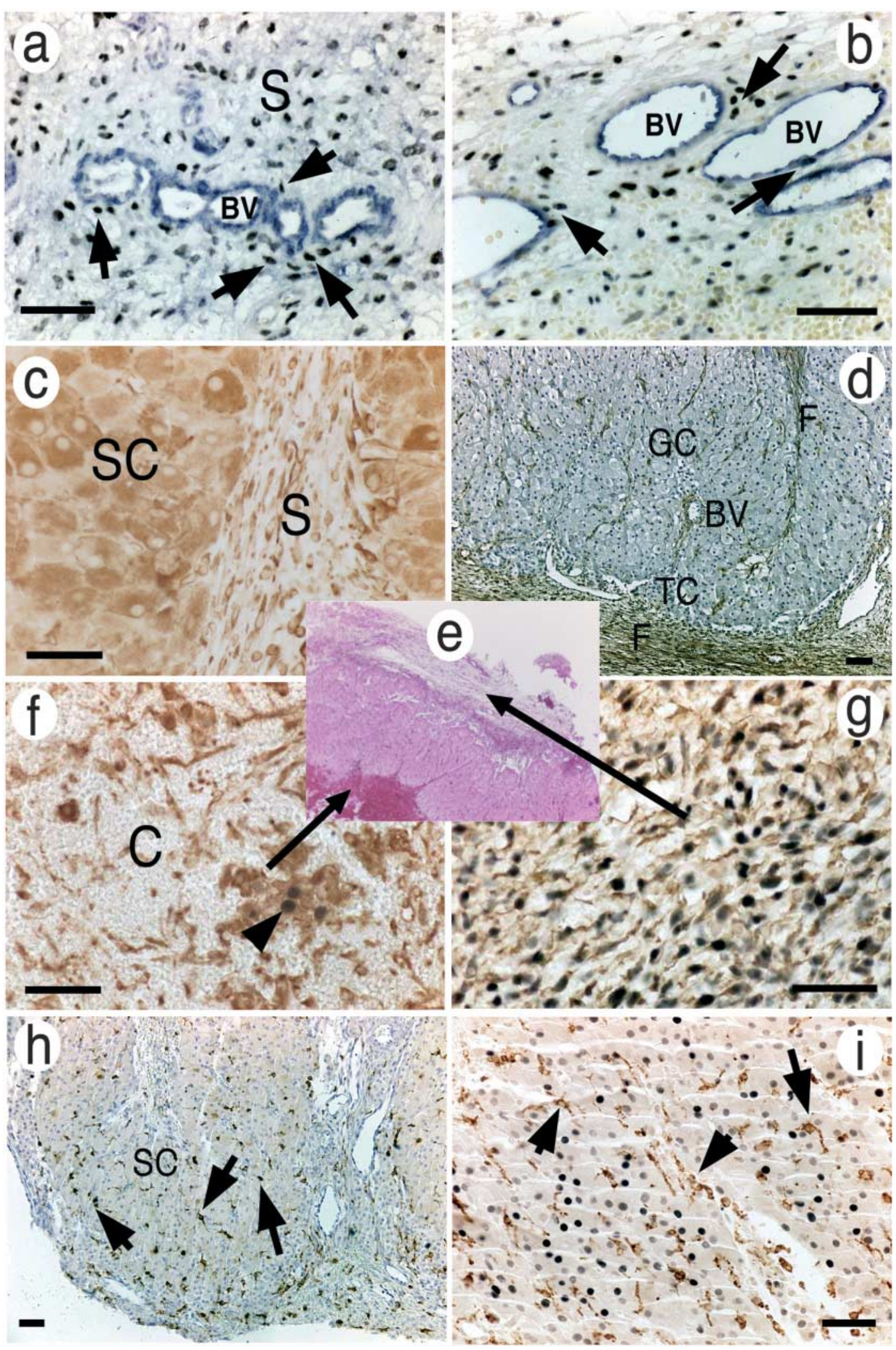


progesterone receptor immunostaining in granulosa-lutein cells confirms the observations of Hild-Petito \& Fazleabas (1997) in the primate corpus luteum. Therefore, although progesterone may function as a paracrine molecule in the corpus luteum, it may also have intracrine effects, as these are the cells responsible for progesterone synthesis. Therefore the steroidogenic cells have receptors to two potentially trophic hormones (hCG and progesterone) and dissecting the independent effect of each is difficult. It has been suggested that progesterone itself is involved in its own synthesis (Rothchild 1996).

There are certainly some effects of progesterone on luteal steroidogenic cells. Tissue inhibitor of matrix metalloproteinases-1 (TIMP-1) is a major product of granulosa-lutein cells (Duncan et al. 1996b) and withdrawal of gonadotrophins results in its reduction (Duncan et al. 1996c). Interestingly, withdrawal of progesterone using RU486 in luteinised granulosa cell cultures also inhibited TIMP-1 expression (Morgan et al. 1994) in the presence of constant gonadotrophin concentrations. Progesterone can directly promote luteinised granulosa cell survival (Makrigiannakis et al. 2000) and influence the expression of $\mathrm{LH}$ receptors (Jones et al. 1992) and steroidogenic enzymes (Chaffin et al. 2000). It is therefore possible that progesterone withdrawal has a direct effect on steroidogenic cell function and further studies are required.

We did not detect progesterone receptors on macrophages at any stage of the luteal phase. Immune cells are important mediators of luteal and ovarian function (Brännström \& Norman 1993, Bukulmez \& Arici 2000). Macrophages increase during luteolysis in many different species (Naftalin et al. 1997) and macrophage accumulation is not present during simulated early pregnancy (Duncan et al. 1998a). The hCG-responsive luteal cell product affecting macrophage migration does not therefore appear to be progesterone. Some immune cells, however, do express steroid receptors. It has recently been shown that uterine natural killer cells have genomic receptors to some steroid hormones (Henderson et al. 2003), but interestingly not progesterone. Another molecule, such as monocyte chemotactic protein-1 (MCP-1), must be involved in the regulation of macrophage influx (Penny 2000). MCP-1 does not appear to be a granulosa luteal cell product as it has a perivascular localisation in the human corpus luteum (Senturk et al. 1998). It is possible that it is expressed by perivascular fibroblasts that express genomic progesterone receptors and progesterone again is implicated as a potential regulator of macrophage influx. Further functional studies are clearly required to dissect this pathway.

The endothelial cells and pericytes of blood vessels did not express progesterone receptors at any stages of the luteal phase. Luteal rescue with hCG results in vascular changes involving an increase in endothelial cell and pericyte cell area (Wulff et al. 2001a) but these cells do not express LH/hCG receptors (Duncan et al. 1996a). However, they do have receptors to vascular endothelial growth factor (VEGF), a granulosa-luteal cell product (Wulff et al. 2000), and inhibition of VEGF in vivo significantly inhibits the development of the luteal vasculature (Wulff et al. 2001b). Steroidogenic cell VEGF expression is increased by hCG during luteal rescue (Wulff et al. 2000). In vitro, luteinised granulosa cells respond to hCG by secreting both progesterone and VEGF (Christenson \& Stouffer 1997). It seems likely that the major hCG-regulated paracrine regulator of the luteal vasculature is VEGF. However, the cellular sources of VEGF in the corpus luteum express progesterone receptors. Whether progesterone has a local role in the expression of VEGF remains to be determined.

We have demonstrated that there are at least two different type of fibroblast in the corpus luteum: those that express genomic progesterone receptors and those that do not. The contribution of fibroblasts in different tissues has been a neglected area of study. What is clear is that fibroblasts from different tissues have different characteristics (Fries et al. 1994). In addition, different types of fibroblasts within tissues may have different phenotypes (Grupp \& Muller 1999). As perivascular and stromal fibroblasts have potentially important roles in the development and regression of the corpus luteum, further work on ovarian fibroblasts is required.

Figure 3 (a) Section of a mid-luteal corpus luteum immunostained with $\alpha$-SMA, to localise pericytes (blue) and progesterone receptors (black). A blood vessel (BV) in the stromal area (S) is demonstrated. Pericytes have no progesterone receptors but other cells neighbouring the blood vessel do (arrows). (b) Another mid-luteal corpus luteum immunostained with CD31, to localise endothelial cells (blue) and progesterone receptors (black). Endothelial cells do not have progesterone receptors but some neighbouring stromal cells (arrows) do. (c) Immunostaining of a mid-luteal corpus luteum with vimentin (brown). The fibroblasts in the stroma (S) immunostain as do the steroidogenic cells (SC). (d) The same corpus luteum immunostained with an antibody specific to fibroblasts (brown). Fibroblasts (F) stain in the stroma and perivascular regions. This section is counterstained with haematoxylin to highlight granulosa-lutein (GC), theca-lutein (TC) cells and blood vessels (BV). (e) Haematoxylinand eosin-stained section of a mid-luteal corpus luteum to illustrate the central clot and the peripheral stroma (arrows). (f) Dual immunostaining of a mid-luteal corpus luteum with vimentin (brown) and progesterone receptors (black). This area is from the central clot (C) showing scattered fibroblasts that do not immunostain for progesterone receptors. A small clump of granulosa-lutein cells can be seen in this clot (arrowhead) identified by the nuclear and cell morphology and the frequent identification of such cells in sections stained with $3 \beta-\mathrm{HSD}$. As expected, these immunostain for progesterone receptors and form a useful internal control. (g) The same slide as (f) showing the peripheral stroma. These fibroblasts (brown) do express immunodetectable progesterone receptors (black). (h) Section of a late luteal corpus luteum immunostained for CD68 to demonstrate macrophages (brown) and counterstained with haematoxylin. These macrophages (arrows) can be seen within the steroidogenic cell layer (SC). (i) Another late luteal corpus luteum with dual staining for macrophages (brown) and progesterone receptors (black). Macrophage nuclei can be clearly identified (arrows) and they never express immunodetectable genomic progesterone receptors. Scale bars $=50 \mu \mathrm{m}$. 
It has been appreciated for a long time that not all the effects of progesterone can be explained by genomic progesterone receptors (Bramley 2003). Recently, two potential related membrane progesterone receptors have been cloned and sequenced (Zhu et al. 2003). These have a wide expression profile. It is still not known whether these are expressed on the various cell types in the human corpus luteum and these studies are underway. However, it is known that the corpus luteum does have membranelinked progesterone-binding activity (Bramley et al. 2002). The role of these receptors is not clear but their presence offers further potentials for progesterone as a paracrine signalling molecule. Clearly, if progesterone has effects on cells in vitro, careful experiments with specific inhibitors are required to dissect possible membrane and genomic actions.

What is clear from these studies is that progesterone receptors are found in the same cell types at all stages of the luteal phase. Although it might have been expected that progesterone receptor immunostaining would be reduced in the late luteal phase (Suzuki et al. 1994), these studies confirm that all cell types with progesterone receptors maintain the potential to respond to progesterone in the late luteal phase. Indeed, these studies were focussed on the localisation of progesterone receptors rather than subtle changes in dual-staining intensities. Although we have optimised our sensitive assay to give clear, remarkably consistent positive or negative staining, we are aware that there may be genomic progesterone receptors in cells at low levels that cannot be detected by immunohistochemistry, or changes in expression levels that cannot be detected using dual-staining protocols.

Although it has been known for many years that the corpus luteum expresses genomic receptors to the progesterone it produces, the role of these receptors is not clear (Stouffer 2003). Inhibition of progesterone in vivo has endocrine and paracrine effects (Duffy et al. 1994) and these are difficult to dissect and interpret (Duffy \& Stouffer 1997, Stouffer 2003). There are parallels between luteal remodelling and endometrial remodelling (Curry \& Osteen 2003) and changing concentrations of progesterone have a clearly defined role in the later. It is likely that progesterone has some parallel paracrine roles in the corpus luteum. Now that we know the cell types to focus on, further interventional and in vitro studies are required to dissect and characterise these roles further.

\section{Acknowledgements}

The authors would like to acknowledge Dr Hamish Fraser for helpful discussion. We also acknowledge the skilled technical help of Clare Balfour. J A M was supported during her studentship by PPP Healthcare. W C D gratefully acknowledges the support of a project grant from the Wellcome Trust.

\section{References}

Bramley T 2003 Non-genomic progesterone receptors in the mammalial ovary: some unresolved issues. Reproduction 125 3-15.

Bramley TA, Menzies GS, Rae MT \& Scobie G 2002 Non genomic steroid receptors in the bovine ovary. Domestic Animal Endocrinology 23 3-12.

Brännström M \& Norman RJ 1993 Involvement of leukocytes and cytokines in the ovulatory process and corpus luteum function. Human Reproduction 8 1762-1775.

Bukulmez O \& Arici A 2000 Leukocytes in ovarian function. Human Reproduction Update 6 1-15.

Chaffin CL, Dissen GA \& Stouffer RL 2000 Hormonal regulation of steroidogenic enzyme expression in granulosa cells during the peri-ovulatory interval in monkeys. Molecular Human Reproduction $611-18$.

Christenson LK \& Stouffer RL 1997 Follicle-stimulating hormone and luteinizing hormone/chorionic gonadotropin stimulation of vascular endothelial growth factor production by macaque granulosa cells from pre- and periovulatory follicles. Journal of Clinical Endocrinology and Metabolism 82 2135-2142.

Curry TE Jr \& Osteen KG 2003 The matrix metalloproteinase system: changes, regulation, and impact throughout the ovarian and uterine reproductive cycle. Endocrine Reviews 24 428-465.

Duffy DM \& Stouffer RL 1997 Gonadotropin versus steroid regulation of the corpus luteum of the rhesus monkey during stimulated early pregnancy. Biology of Reproduction 57 1451-1460.

Duffy DM, Hess DL \& Stouffer RL 1994 Acute administration of a $3 \beta$-hydroxysteroid dehydrogenase inhibitor to rhesus monkeys at the midluteal phase of the menstrual cycle: evidence for possible autocrine regulation of the primate corpus luteum by progesterone. Journal of Clinical Endocrinology and Metabolism 79 1587-1594.

Duffy DM, Wells TR, Haluska GJ \& Stouffer RL 1997 The ratio of progesterone receptor isoforms changes in the monkey corpus luteum during the luteal phase of the menstrual cycle. Biology of Reproduction 57 693-699.

Duncan WC 2000 The human corpus luteum: remodelling during luteolysis and maternal recognition of pregnancy. Reviews of Reproduction 5 12-17.

Duncan WC, McNeilly AS, Fraser HM \& Illingworth PJ 1996a Luteinizing hormone receptor in the human corpus luteum: lack of down regulation during maternal recognition of pregnancy. Human Reproduction 112291 -2297.

Duncan WC, McNeilly AS \& Illingworth PJ $1996 b$ Expression of tissue inhibitor of metalloproteinases- 1 in the human corpus luteum after luteal rescue. Journal of Endocrinology 148 59-67.

Duncan WC, Illingworth PJ \& Fraser HM 1996c Expression of tissue inhibitor of metalloproteinases-1 in the primate ovary during induced luteal regression. Journal of Endocrinology 151 203-213.

Duncan WC, Rodger FE \& Illingworth PJ 1998a The human corpus luteum: reduction in macrophages during maternal recognition of pregnancy. Human Reproduction 13 2435-2442.

Duncan WC, McNeilly AS \& Illingworth PJ 1998b The effect of luteal 'rescue' on the expression and localization of matrix metalloproteinases and their tissue inhibitors in the human corpus luteum. Journal of Clinical Endocrinology and Metabolism $832470-2478$.

Duncan WC, Cowen GM \& Illingworth PJ 1999 Steroidogenic enzyme expression in human corpora lutea in the absence and presence of exogenous human chorionic gonadotrophin. Molecular Human Reproduction 5 291-298.

Fries KM, Blieden T, Looney RJ, Sempowski GD, Silvera MR, Willis RA \& Phipps RP 1994 Evidence of fibroblast heterogeneity and the role of fibroblast subpopulations in fibrosis. Clinical Immunology and Immunopathology 72 283-292.

Grupp C \& Muller GA 1999 Renal fibroblast culture. Experimental Nephrology 7 377-385.

Henderson TA, Saunders PTK, Moffet-King A, Groome NP \& Critchley HOD 2003 Steroid receptor expression in uterine natural killer 
cells. Journal of Clinical Endocrinology and Metabolism $\mathbf{8 8}$ 440-449.

Hild-Petito S \& Fazleabas AT 1997 Expression of steroid receptors and steroidogenic enzymes in the baboon (Papio anubis) corpus luteum during the menstrual cycle and early pregnancy. Journal of Clinical Endocrinology and Metabolism 82 955-962.

Hild-Petito S, Stouffer RL \& Brenner RM 1988 Immunohistochemical localisation of estradiol and progesterone receptors in the monkey ovary throughout the menstrual cycle. Endocrinology 123 2896-2905.

Horie K, Takakura K, Fujiwara H, Lioa S \& Mori T 1992 Immunohistochemical localization of androgen receptor in the human ovary throughout the menstrual cycle in relation to oestrogen and progesterone receptor expression. Human Reproduction 7 184-190.

Jones LS, Ottobre JS \& Pate JL 1992 Progesterone regulation of luteinizing hormone receptors on cultured bovine luteal cells. Molecular and Cellular Endocrinology 85 33-39.

Makrigiannakis A, Coukos G, Christofidou-Solomidou M, Montas S \& Coutifaris C 2000 Progesterone is an autocrine/paracrine regulator of human granulosa cell survival in vitro. Annals of the New York Academy of Science 900 16-25.

Morgan A, Keeble SC, London SN, Mase KN \& Curry TE Jr 1994 Antiprogesterone (RU486) effects on metalloproteinase inhibitor activity in human and rat granulosa cells. Fertility and Sterility $\mathbf{6 1}$ 949-955.

Naftalin DM, Bove SE, Keyes PL \& Townson DH 1997 Estrogen withdrawal induces macrophage invasion in the rabbit corpus luteum. Biology of Reproduction 56 1175-1180.

Nishimori K, Dunkel L, Hsueh AJW, Yamoto M \& Nakano R 1995 Expression of luteinizing hormone and chorionic gonadotropin receptor messenger ribonucleic acid in human corpora lutea during menstrual cycle and pregnancy. Journal of Clinical Endocrinology and Metabolism 80 1444-1448.

Penny LA 2000 Monocyte chemoattractant protein 1 in luteolysis. Reviews of Reproduction 5 63-66.

Rothchild I 1996 The corpus luteum revisited: are the paradoxical effects of RU486 a clue to how progesterone stimulates its own secretion? Biology of Reproduction 55 1-4.

Salamonsen LA, Butt A, Hammond FR, Garcia S \& Zhang J 1997 Production of endometrial matrix metalloproteinases, but not their tissue inhibitors, is modulated by progesterone withdrawal in an in vitro model for menstruation. Journal of Clinical Endocrinology and Metabolism 82 1409-1415.
Senturk LM, Seli E, Gutierrez LS, Mor G, Zeyneloglu HB \& Arici A 1998 Monocyte chemotactic protein-1 in human corpus luteum. Molecular Human Reproduction 5 697-702.

Slayden OD, Zelinski-Wooten MB, Stouffer RL \& Brenner RM 1994 Radioligand binding assay of progesterone receptors in the primate corpus luteum after in vivo treatment with the $3 \beta$-hydroxysteroid dehydrogenase inhibitor, trilostane. Journal of Clinical Endocrinology and Metabolism 79 620-626.

Stouffer RL 2003 Progesterone as a mediator of gonadotrophin action in the corpus luteum: beyond steroidogenesis. Human Reproduction Update 9 99-117.

Stouffer RL, Ottobre JS \& VandeVoort CA 1987 Regulation of the primate corpus luteum during early pregnancy. In The Primate Ovary, pp 207-220. Ed. RL Stouffer. New York: Plenum Press.

Suzuki T, Sasano H, Kimura N, Tamura M, Fukaya T, Yajima A \& Nagura H 1994 Immunohistochemical distribution of progesterone, androgen and oestrogen receptors in the human ovary during the menstrual cycle: relationship to expression of steroidogenic enzymes. Human Reproduction 9 1589-1595.

Vega M \& Devoto L 1997 Autocrine/paracrine regulation of normal human corpus luteum development. Seminars in Reproductive Endocrinology 15 353-362.

Wulff C, Wilson H, Largue P, Duncan WC, Armstrong D \& Fraser HM 2000 Localisation and changes in angiopoietin messenger ribonucleic acid in the human corpus luteum. Journal of Clinical Endocrinology and Metabolism 85 4302-4309.

Wulff C, Dickson SE, Duncan WC \& Fraser HM 2001a Angiogenesis in the human corpus luteum: simulated early pregnancy by HCG treatment is associated with both angiogenesis and vessel stabilization. Human Reproduction 16 2515-2524.

Wulff C, Wilson H, Rudge JS, Wiegand SJ, Lunn SF \& Fraser HM $2001 \mathrm{~b}$ Luteal angiogenesis: prevention and intervention by treatment with vascular endothelial growth factor trap (A40). Journal of Clinical Endocrinology and Metabolism 86 3377-3386.

Zhu Y, Bond J \& Thomas P 2003 Identification, classification and partial characterization of genes in humans and other vertebrates homologous to a fish membrane progestin receptor. PNAS $\mathbf{1 0 0}$ $2237-2242$.

Received 17 October 2003

First decision 12 January 2003

Revised manuscript received 19 May 2004

Accepted 14 June 2004 